The University of Maine

\title{
DigitalCommons@UMaine
}

Earth Science Faculty Scholarship

Earth Sciences

7-4-2011

\section{An ice-core proxy for northerly air mass incursions into West Antarctica}

Daniel D. Dixon

Daniel.Dixon@umit.maine.edu

Paul Andrew Mayewski

University of Maine, paul.mayewski@maine.edu

Ian D. Goodwin

Gareth J. Marshall

Rhaelene Freeman

See next page for additional authors

Follow this and additional works at: https://digitalcommons.library.umaine.edu/ers_facpub

Part of the Geochemistry Commons, and the Glaciology Commons

\section{Repository Citation}

Dixon, Daniel D.; Mayewski, Paul Andrew; Goodwin, Ian D.; Marshall, Gareth J.; Freeman, Rhaelene; Maasch, Kirk A.; and Sneed, Sharon B., "An ice-core proxy for northerly air mass incursions into West Antarctica" (2011). Earth Science Faculty Scholarship. 176. https://digitalcommons.library.umaine.edu/ers_facpub/176 


\section{Authors}

Daniel D. Dixon, Paul Andrew Mayewski, Ian D. Goodwin, Gareth J. Marshall, Rhaelene Freeman, Kirk A. Maasch, and Sharon B. Sneed 


\title{
An ice-core proxy for northerly air mass incursions into West Antarctica
}

\author{
Daniel A. Dixon, ${ }^{a *}$ Paul A. Mayewski, ${ }^{a}$ Ian D. Goodwin, ${ }^{b}$ Gareth J. Marshall, ${ }^{\mathrm{c}}$ \\ Rhaelene Freeman, ${ }^{\mathrm{b}}$ Kirk A. Maasch ${ }^{\mathrm{a}}$ and Sharon B. Sneed ${ }^{\mathrm{a}}$ \\ ${ }^{a}$ Climate Change Institute and Department of Earth Sciences, University of Maine, Orono, ME 04469-5790, USA \\ ${ }^{\mathrm{b}}$ Climate Risk CoRE and Environmental Science, Macquarie University, Sydney, NSW 2109, Australia \\ ${ }^{\mathrm{c}}$ British Antarctic Survey, High Cross, Madingley Road, Cambridge CB3 OET, UK
}

\begin{abstract}
A 200-year proxy for northerly air mass incursions (NAMI) into central and western West Antarctica is developed from the examination of 19 shallow (21-150 m deep) Antarctic ice-core non-sea-salt (nss) $\mathrm{Ca}^{2+}$ concentration records. The NAMI proxy reveals a significant rise in recent decades. This rise is unprecedented for at least the past 200 years and is coincident with anthropogenically driven changes in other large-scale Southern Hemisphere (SH) environmental phenomena such as greenhouse gas (GHG) induced warming, ozone depletion, and the associated intensification of the SH westerlies. The Hysplit trajectory model is used to examine air mass transport pathways into West Antarctica. Empirical orthogonal function analysis, in combination with trajectory results, suggests that atmospheric circulation is the dominant factor affecting $\mathrm{nssCa}^{2+}$ concentrations throughout central and western West Antarctica. Ozone recovery will likely weaken the spring-summer SH westerlies in the future. Consequently, Antarctica could lose one of its best defences against SH GHG warming. Copyright (c) 2011 Royal Meteorological Society
\end{abstract}

KEY WORDS Antarctic; glaciochemistry; Southern Hemisphere westerlies; climate change; International Trans Antarctic Scientific Expedition; atmospheric circulation

Received 14 May 2010; Revised 13 April 2011; Accepted 26 April 2011

\section{Introduction}

Globally, record-breaking warming, glacier retreat, and ice shelf collapse on the Antarctic Peninsula reveal the consequences of anthropogenic source greenhouse gas (GHG) warming and ozone depletion coupled with the natural magnifying capacity of ocean ice cover removal (Rignot et al., 2004; Scambos et al., 2004; van den Broeke, 2005; Turner et al., 2006; Lubin et al., 2008; ACCE, 2009). To the south, West Antarctica has undergone significant $\left(>0.1^{\circ} \mathrm{C} /\right.$ decade since 1950) warming in recent decades (Steig et al., 2009) and weak yet statistically significant warming trends are beginning to emerge at some East Antarctic interior and coastal stations since 1992 (Monaghan et al., 2008). Much of the foregoing is linked to the behaviour of the southern annular mode (SAM) (Thompson and Solomon, 2002; Schneider et al., 2004). The SAM is the dominant pattern of Southern Hemisphere ( $\mathrm{SH})$ atmospheric variability south of $20^{\circ} \mathrm{S}$ and its index describes the relative anomalies in the meridional pressure gradient between the sub-Antarctic and middle latitudes. Since instrumental records began, in the 1950s, the SAM has been trending into a positive high-index state (Thompson et al., 2000;

\footnotetext{
* Correspondence to: Daniel A. Dixon, Climate Change Institute and Department of Earth Sciences, University of Maine, Orono, ME 044695790, USA. E-mail: daniel.dixon@maine.edu
}

Marshall, 2003). Since the late 1970s there has been a rise in the rate of increase as a consequence of the thermal gradient amplification induced by ozone depletion and GHG warming (Thompson et al., 2000; ACCE, 2009). As a result, there has been a contraction of the Antarctic circumpolar vortex (ACV), the largescale cyclonic circulation of the troposphere centred over Antarctica, and intensification of the SH westerlies that form at the edge of the ACV (Randel and Wu, 1999; Thompson and Solomon, 2002; Crook et al., 2008). This intensification has thus far isolated most of Antarctica from the impacts of GHG warming (ACCE, 2009) and has probably led to a deepening of the Amundsen Sea Low (ASL) pressure system (Turner et al., 2009). The more positive SAM has also weakened katabatic winds over much of East Antarctica resulting in a less turbulent heat flux into the surface (van den Broeke and van Lipzig, 2004). Understanding how long these conditions persist and how rapidly the westerlies' barrier can be invaded is critical in assessing the future of SH climate and sea level rise.

To begin to address these questions we examine an icecore record array that reveals increases in extra-Antarctic source dust-laden air masses into coastal and central West Antarctica during the last century and a rapid rise in the rate of increase during the last three decades (Figure 1). These dust records offer a proxy for the relative intensity of extra-Antarctic continental source air mass incursions 

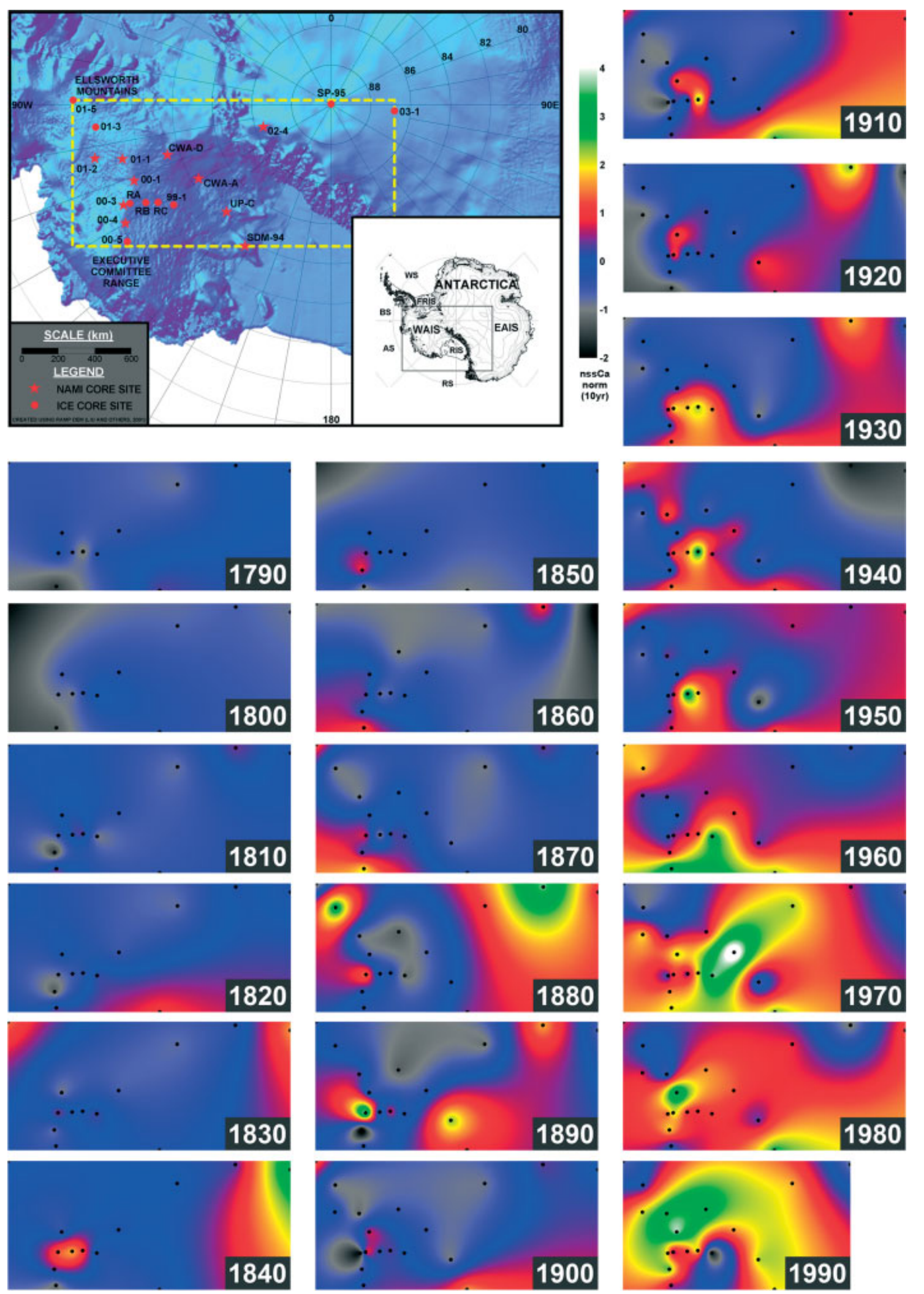

Figure 1. Polar stereographic shaded relief map of Antarctica showing the location of ice cores used in this study. Cores marked by stars are used to construct the NAMI proxy. Inset: Antarctic location map. Area denoted by yellow dashed line indicates geographic location of boxes shown below. Boxes: decadal contour plots showing the spatio-temporal distribution of normalized nssCa concentrations from the suite of 19 cores. Black dots within each contour box indicate which ice cores were used to construct the plot. Note: 1990 contour box is smaller because the 03-1 core is not used for that decade. EAIS, East Antarctic ice sheet; WAIS, West Antarctic ice sheet; RIS, Ross Ice Shelf; FRIS, Filchner-Ronne Ice Shelf; RS, Ross Sea; AS, Amundsen Sea; BS, Bellingshausen Sea; WS, Weddell Sea. 
(storms) into West Antarctica, and by association the strength of the SH westerlies and the ASL that is the graveyard for many of these storms. Hereafter, we will refer to this as the northerly air mass incursion (NAMI) proxy.

\section{Methods and results}

Previous work demonstrates that statistically significant correlations exist between glaciochemical concentrations and instrumented climate records in and around Antarctica. Examples include strong associations between icecore $\mathrm{Na}^{+}$concentrations and the ASL pressure system (Kreutz et al., 2000; Kaspari et al., 2004), icecore methanesulphonic acid concentrations and sea ice extent (Welch et al., 1993; Meyerson et al., 2002; Curran et al., 2003; Abram et al., 2007), ice-core stable isotopes and temperature (Schneider et al., 2004, 2006), and icecore non-sea-salt- $\mathrm{Ca}^{2+}$ (nssCa) concentrations used as a NAMI proxy in this study. A previous ice-core nssCa study (Yan et al., 2005) established that a statistically significant positive relationship exists between the strength of $\mathrm{SH}$ westerlies and nssCa concentrations in two West Antarctic ice cores (SDM-94 and 00-1) from 1948 to 2002. In this study, we expand these findings using an array of 19 ice-core nssCa records that include the original SDM-94 and 00-1 sites (Figure 1) and expand the significance of the proxy based on investigation of the sources and transport pathways of nssCa.

The 19 ice cores used to produce our NAMI proxy range in depth from 21 to $150 \mathrm{~m}$ and span the time period 850-2000 AD (Table I). The majority of the cores
(99-1, 00-1, 00-3, 00-4, 00-5, 01-1, 01-2, 01-3, $01-5,02-4$, and 03-1) used in this study were collected during seven US ITASE (International Trans Antarctic Scientific Expedition) field seasons (Mayewski et al., 2005; Mayewski et al., 2009). The US ITASE cores were melted using the University of Maine continuous melter system (Osterberg et al., 2006) and are sub-annually sampled (except for 03-1) for their entire depth (see Table I for more information). This sampling resolution captures the clear seasonal signal present in several of the glaciochemical series and allows determination of a relative dating accuracy of better than 1 year (Dixon et al., 2004; Steig et al., 2005).

All samples were measured for $\mathrm{Na}^{+}, \mathrm{K}^{+}, \mathrm{Mg}^{2+}, \mathrm{Ca}^{2+}$, $\mathrm{Cl}^{-}, \mathrm{NO}_{3}{ }^{-}$, and $\mathrm{SO}_{4}{ }^{2-}$, using a Dionex ${ }^{\circledR} \mathrm{DX}-500$ ion chromatograph coupled to a Gilson ${ }^{\circledR}$ autosampler. To determine anion $\left(\mathrm{Cl}^{-}, \mathrm{SO}_{4}{ }^{2-}\right.$, and $\left.\mathrm{NO}_{3}{ }^{-}\right)$and cation $\left(\mathrm{Na}^{+}, \mathrm{Ca}^{2+}, \mathrm{Mg}^{2+}\right.$, and $\left.\mathrm{K}^{+}\right)$concentrations we used an IonPac AS-11 hydroxide-selective anion-exchange column and an IonPac CS-12A cation-exchange column, respectively. $\mathrm{Ca}^{2+}$ concentrations have an accuracy of better than $0.1 \mu \mathrm{g} / \mathrm{l}$. The nssCa concentrations were calculated using the standard seawater ratio (Holland, 1978) of $\mathrm{Na}^{+}, \mathrm{K}^{+}, \mathrm{Mg}^{2+}, \mathrm{Ca}^{2+}, \mathrm{Cl}^{-}$, and $\mathrm{SO}_{4}{ }^{2-}$ after the method outlined by O'Brien et al. (1995) that performs an iterative test against each species to determine the most conservative sea-salt indicator per sample.

The chemical concentration of each sample is reported rather than flux (flux $=$ concentration $\times$ accumulation rate) because dry deposition rates for inland Antarctica are not well constrained and there is no significant correlation between nssCa concentration and accumulation

Table I. Data for ice cores.

\begin{tabular}{|c|c|c|c|c|c|c|c|}
\hline $\begin{array}{l}\text { Location } \\
\text { (core) }\end{array}$ & $\begin{array}{l}\text { Latitude } \\
\qquad\left({ }^{\circ} \mathrm{N}\right)\end{array}$ & $\begin{array}{l}\text { Longitude } \\
\left({ }^{\circ} \mathrm{E}\right)\end{array}$ & $\begin{array}{l}\text { Elevation } \\
\text { (m) }\end{array}$ & $\begin{array}{l}\text { Depth } \\
(\mathrm{m})\end{array}$ & $\begin{array}{l}\text { Core age } \\
\text { (year AD) }\end{array}$ & $\begin{array}{l}\text { Mean acc. rate } \\
\quad(\mathrm{cm} \text { weq) }\end{array}$ & References \\
\hline $99-1$ & -80.6200 & -122.6300 & 1350 & 58 & $1713-1988$ & 13 & Dixon et al., 2004 \\
\hline $00-1$ & -79.3831 & -111.2390 & 1791 & 105 & $1651-1997$ & 21.8 & Dixon et al., 2004 \\
\hline $00-3$ & -78.4330 & -115.9172 & 1742 & 60 & $1888-1999$ & 38.9 & This study \\
\hline $00-4$ & -78.0829 & -120.0764 & 1697 & 58 & $1799-1999$ & 19 & Dixon et al., 2004 \\
\hline $00-5$ & -77.6830 & -123.9950 & 1828 & 60 & $1708-1995$ & 13.6 & Dixon et al., 2004 \\
\hline $01-1$ & -79.1597 & -104.9672 & 1842 & 73 & $1857-2000$ & 33.7 & This study \\
\hline $01-2$ & -77.8436 & -102.9103 & 1336 & 71 & $1890-2000$ & 42.9 & Dixon et al., 2004 \\
\hline $01-3$ & -78.1202 & -95.6463 & 1620 & 71 & $1859-2000$ & 32.6 & Dixon et al., 2004 \\
\hline $01-5$ & -77.0593 & -89.1376 & 1239 & 114 & $1781-2000$ & 38.9 & Dixon et al., 2004 \\
\hline $02-4$ & -86.5025 & -107.9903 & 2586 & 72 & $1593-1997$ & 11 & This study \\
\hline $03-1$ & -86.8400 & 95.3100 & 3124 & 21 & $1800-1982$ & 4.6 & This study \\
\hline SP-95 & -90.0000 & 0.0000 & 2850 & 71 & 1487-1990 & 7.3 & Meyerson et al., 2002 \\
\hline SDM-94 & -81.6480 & -148.7900 & 620 & 150 & $1890-1995(850)$ & 11.9 & Kreutz et al., 1997 \\
\hline UP-C & -82.4391 & -135.9719 & 525 & 28 & 1870-1996 & 12.1 & This study \\
\hline CWA-A & -82.3671 & -119.2855 & 950 & 93.5 & 1934-1994 (1741) & 13.2 & Reusch et al., 1999 \\
\hline CWA-D & -81.3723 & -107.2750 & 1930 & 50.5 & $1952-1994(1851)$ & 19.9 & Reusch et al., 1999 \\
\hline RIDS-A & -78.7300 & -116.3300 & 1740 & 150 & $1831-1996$ (1507) & 23.3 & Kreutz et al., 2000a \\
\hline RIDS-B & -79.4600 & -118.0500 & 1603 & 60 & $1925-1996(1691)$ & 15 & Kreutz et al., 2000a \\
\hline RIDS-C & -80.0100 & -119.4300 & 1530 & 60 & 1905-1996 (1594) & 11.2 & Kreutz et al., 2000a \\
\hline
\end{tabular}

Note that ice core ages in brackets show full core age including multi-annual data (2.5-year), numbers without brackets in this column indicate the part of the core that is sampled sub-annually. Mean acc. rate = mean annual accumulation rate for the length of each sub-annual record (cm weq $=\mathrm{cm}$ of water equivalent depth). 
rate to justify a flux correction (Dixon et al., 2004). Further, the use of a flux calculation would only serve to enhance the observed signal because nssCa concentrations are already higher close to the coast and would be higher still if multiplied by coastal accumulation rates (as coastal values are higher than those inland).

To better assess the spatio-temporal variability of the nssCa concentrations at each site, all nssCa time series were normalized and the results contoured by decade from 1790 to 1990 (Figure 1). The contour maps highlight the relative magnitude of the nssCa variability from site to site through time. Each decadal value is the mean of the 5 years either side of it, for example, the 1990 decadal value is calculated from all values between 1985 and 1995. As Table I shows, some cores do not have data all the way up to 1995 (03-1, SP-95, CWAA, and CWA-D). For these cores, we calculate the 1990 value using the available data for each core between 1985 and 1995. For the 03-1 core, we use the available data to calculate a 1980 value and do not use the core in the 1990 contour plot. Two of the cores (99-1 and Up-C) contain data gaps. In the case of $\mathrm{Up}-\mathrm{C}$, the gaps are less than 1 year and temporally distributed enough that we do not consider them to alter the decadal values significantly. However, in the case of 99-1, the data gaps are more extensive with values missing for the following time periods: 1995-1988.4, 1963.7-1962.4, and 1957-1943. This results in $\sim 6.6$ years of data missing from the 1990 decadal value calculation, $\sim 3.3$ years missing from the 1960 value, 2 years missing from the 1940 value, and no value at all for 1950. For construction of the contour plots we use all available 99-1 data for the decadal values, but could not use the core for the 1950 plot.
Many of the ice-core records exhibit nssCa concentration increases during the last century (Figure 1). In the last two to three decades, nssCa concentrations in several of these cores (in particular, 00-1, 00-3, 00-4, 01-1, and SDM-94) increase more than $100 \%$ above their mean 1800-1900 values (Table II). These sites are located in central and western West Antarctica directly inland from the Ross Ice Shelf and the Amundsen Sea embayment. Three cores further inland also show similar concentration increases (02-4, CWA-A, and CWA-D). Cores from the East Antarctic interior (03-1 and SP-95) and the eastern segment of West Antarctica (01-3 and 01-5) exhibit no significant change throughout the 1900s. Several sites inland between the main West Antarctic ice divide and the Ross Ice Shelf (00-5, RIDS-A, -B, -C, and 99-1) exhibit a fairly high degree of concentration variability throughout the 1900s with no apparent trends.

The major source of nssCa in polar ice is crustalderived dust (Legrand and Mayewski, 1997). Previous work has shown that the sources of nssCa to West Antarctica are the circum-Antarctic SH continents and ice-free regions within Antarctica (Shaw, 1979; Gayley and Ram, 1985; Tuncel et al., 1989; Bertler et al., 2005). However, only $\sim 2 \%$ of Antarctica is ice-free and the majority of these ice-free areas are located in the Transantarctic Mountains. The Ellsworth Mountains contain a significant ice-free area, but only two of our cores, 01-5 and 01-3, are located close enough for this source to be considered of potential significance.

The Pacific sector of the West Antarctic coastline contains only a tiny ice-free fraction. Tropospheric stormtrack pathways into West Antarctica pass over only a limited section of the aforementioned ice-free areas. Because change in the extent of these ice-free areas has

Table II. Relative nssCa concentration rise.

\begin{tabular}{lcccccccccc}
\hline Core & 1990 & 1980 & 1970 & 1960 & 1950 & 1940 & 1930 & 1920 & 1910 & 1900 \\
\hline $03-1$ & - & 1.3 & 0.8 & 1.0 & 1.2 & 0.5 & 1.0 & 0.5 & 1.3 & 1.0 \\
$02-4$ & 4.6 & 3.2 & 5.4 & 2.3 & 2.9 & 1.7 & 1.1 & 1.6 & 1.0 & 0.5 \\
$01-1$ & 2.2 & 1.0 & 1.3 & 1.3 & 1.4 & 1.6 & 1.2 & 1.0 & 0.9 & 0.8 \\
$01-2$ & 1.7 & 1.3 & 1.7 & 1.1 & 0.7 & 0.7 & 0.7 & 0.6 & 0.7 & 1.0 \\
$01-3$ & 0.9 & 0.9 & 0.7 & 1.5 & 0.9 & 1.1 & 0.9 & 0.8 & 0.7 & 0.6 \\
$01-5$ & 0.9 & 1.2 & 0.9 & 1.5 & 1.5 & 1.5 & 0.8 & 0.9 & 1.3 & 1.4 \\
$00-1$ & 3.7 & 3.6 & 2.6 & 1.1 & 0.9 & 0.9 & 1.2 & 2.0 & 2.1 \\
$00-3$ & 3.9 & 3.4 & 2.6 & 2.6 & 2.6 & 2.6 & 3.0 & 2.2 & 1.3 \\
$00-4$ & 2.1 & 1.9 & 1.8 & 1.5 & 1.3 & 1.0 & 1.2 & 1.1 & 1.1 \\
$00-5$ & 1.2 & 1.0 & 1.8 & 2.4 & 1.3 & 1.6 & 1.5 & 0.5 & 1.1 \\
99-1 & 0.5 & 1.5 & 2.4 & 2.1 & - & 1.3 & 1.7 & 1.0 & 1.0 \\
RIDS-A & 0.9 & 1.7 & 1.3 & 0.9 & 0.9 & 1.3 & 1.6 & 1.3 & 0.9 & 1.1 \\
RIDS-B & 1.8 & 1.7 & 1.4 & 1.6 & 3.0 & 2.0 & 2.2 & 0.7 & 0.8 \\
RIDS-C & 1.8 & 1.3 & 1.8 & 1.4 & 1.6 & 2.2 & 1.8 & 1.2 & 2.0 \\
CWA-A & 10.4 & 8.8 & 24.6 & 7.7 & 5.6 & 6.7 & 1.7 & 0.3 & 0.4 & 1.2 \\
CWA-D & 4.8 & 3.3 & 2.3 & 2.3 & 1.5 & 1.1 & 1.5 & 2.0 & 1.1 \\
SDM-94 & 1.9 & 2.2 & 2.1 & 2.0 & 1.5 & 1.6 & 1.6 & 1.3 & 2.2 & 0.6 \\
UP-C & 1.6 & 1.1 & 0.7 & 1.1 & 0.5 & 0.8 & 0.7 & 1.2 & 1.0 \\
SP-95 & 0.7 & 0.7 & 1.0 & 0.8 & 1.0 & 0.5 & 1.2 & 1.4 & 1.1 \\
\hline
\end{tabular}

Decadal nssCa concentrations where each decadal value is divided by the $1800-1900$ mean value for that core. 
not been reported and they offer a minimal source region, we do not consider the coastal West Antarctic ice-free areas to be a significant contributor to dust loading over the region encompassing the majority of cores used in this study.

The primary SH dust source regions feeding West Antarctica, in order of importance, are Australia, South America, and South Africa (Prospero et al., 2002; Li et al., 2008; De Deckker et al., 2010; Mahowald et al., in press) We calculated 30-day forward trajectories (FT) originating from the southernmost dust source region on each of these SH continents, except Antarctica (Figure 2) using the NOAA Hysplit Model v.4.8 (Draxler and Rolph, 2003) in conjunction with the NCEP/NCAR global atmospheric reanalysis datasets archived on the READY website (ftp://www.ready.noaa.gov/pub/ archives/reanalysis/). The Hysplit model control file included: (1) starting locations $=7$ (each location with a slightly different latitude and longitude, up to $\pm 2^{\circ}$ from the centre of each dust source area), (2) altitude of each starting location $=100 \mathrm{~m}$, (3) top of the model $=30000 \mathrm{~m}$ (agl), and (4) vertical motion = data (default value, uses meteorological model's vertical velocity fields). The FT was run for each of the four seasons for four different years (1980, 1989, 1996, and 1999) with seasonal starting times as follows: 15 December, 15
March, 15 June, and 15 September. These years were chosen to represent the last three decades whilst overlapping the most highly resolved model data.

In each model run, the dust-laden air parcels generally circulate southward from each dust source whereupon they are incorporated into, and circulate around Antarctica embedded in the ACV. Only Australia and South America commonly spawn air masses that reach the Antarctic continent within 30 days of transport from source. We show the 1996 model output for representative SH air mass transport pathways (Figure 2).

As a check on the reliability of the FT trajectories, 30-day back trajectories (BT) from the SDM-94 and 00-1 ice-core sites were also calculated using the same NOAA Hysplit model in conjunction with NCEP/NCAR atmospheric reanalysis (Figure 2). The BT are based on identical model control file setups to the FT runs, the only difference being the start times: 15 January, 15 April, 15 July, and 15 October, in order to cover approximately the same 30-day period as the FT. The BT runs demonstrate that 30 days prior to arrival, air masses approaching SDM-94 and 00-1 frequently travel in a broadly similar pattern; the air masses originate somewhere within the ACV and circulate around the Antarctic continent until they are diverted inland, as synoptic storms, across the Ross, Amundsen, and Bellingshausen Seas. In some
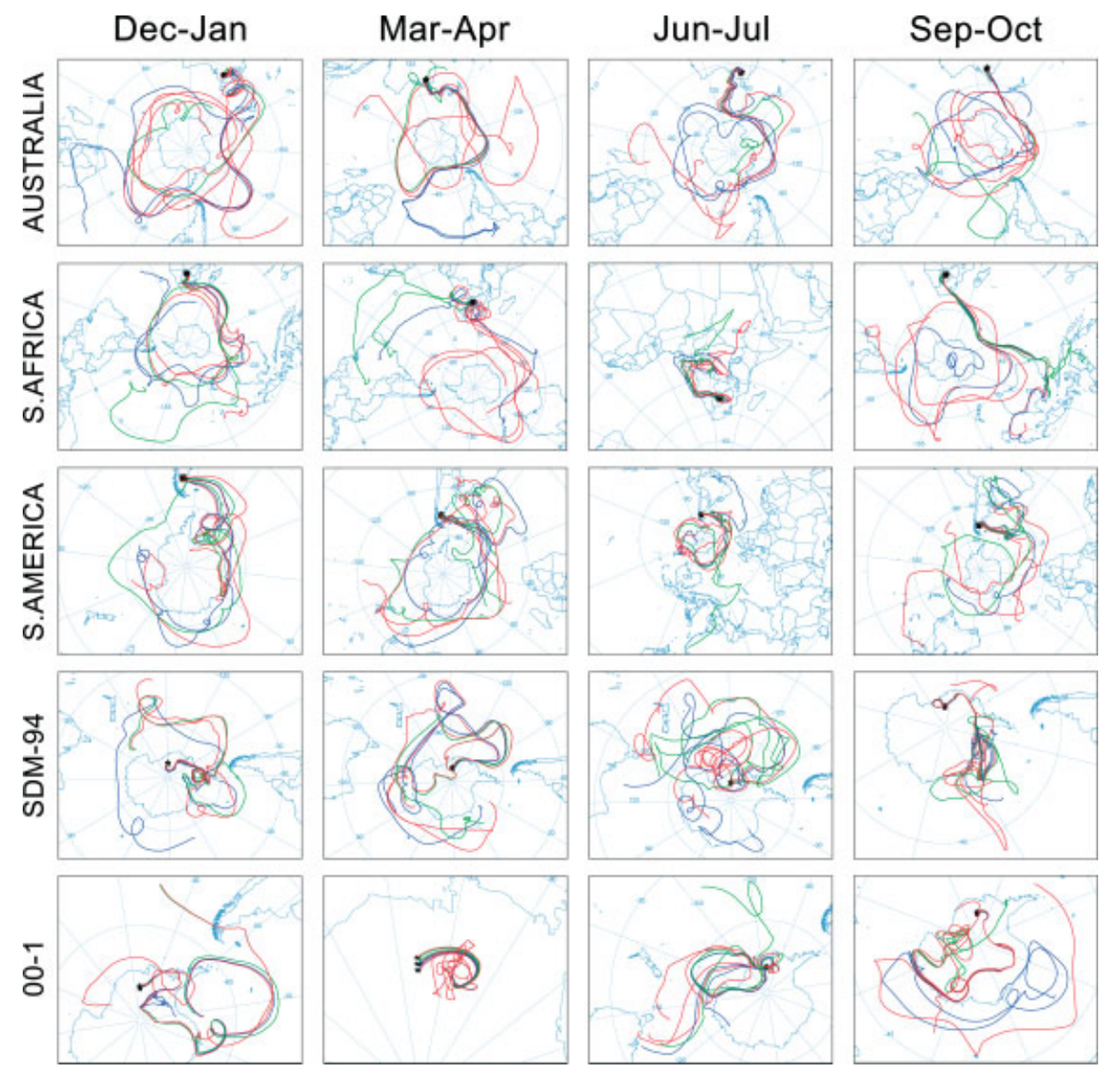

Figure 2. Thirty-day FT for 1996 originating from the southernmost dust source in Australia, South Africa, and South America. Thirty-day BT for 1996 originating from the SDM-94 and 00-1 ice core sites in West Antarctica. Trajectories calculated using the NOAA Hysplit Model (version 4.8) in conjunction with the NCEP/NCAR atmospheric reanalysis (ftp://www.ready.noaa.gov/pub/archives/reanalysis/). 
cases, the air masses reach West Antarctica after being diverted across the Weddell Sea and travelling over the Filchner-Ronne Ice Shelf. After moving inland, the air masses can circulate over the continent for some time before arrival at the core sites and in rare cases circulate randomly over the continent for 30 days or more before arrival. These FT and BT model runs show that dust reaching the West Antarctic ice-core sites in this study is not directly related to a single dust source region. It is a blend from all SH sources that feed into the ACV.

Some site-to-site variability of nssCa concentrations results from the relatively chaotic behaviour of air masses during their transit, via storm incursions, from the ACV to the ice-core sites. To reduce the effects of this variability a NAMI proxy was developed by stacking annually averaged and normalized $02-4,01-1,01-2$, 00-1, 00-3, 00-4, CWA-A, CWA-D, SDM-94, and Up$\mathrm{C}$ nssCa concentration records. We chose these sites for a number of reasons, in order of importance: (1) they all correlate positively to the NCEP/NCAR reanalysis, January to December, $850 \mathrm{mb}$ zonal wind field in the area of the ACV, (2) they exhibit recent nssCa concentration increases with $1980-1990$ values $>100 \%$ above their 1800-1900 means (except Up-C and 01-2), and (3) they are directly in line with lower tropospheric air mass pathways into West Antarctica (except 02-4).

The Up-C and 01-2 cores exhibit slightly weaker recent nssCa concentration increases, 60 and $70 \%$, respectively, and the $02-4$ core is not directly in line with lower tropospheric air mass pathways into West Antarctica. However, all three correlate positively to the NCEP/NCAR reanalysis, January to December, $850 \mathrm{mb}$ zonal wind field in the area of the ACV and were included primarily for this reason. Ten cores are used to construct the NAMI proxy and their nssCa records begin and end on different years. We consider the NAMI proxy valid as long as $50 \%$ or more of the cores are being utilized for a given year. When constructed from sub-annual nssCa data alone, the NAMI proxy spans 1870-1997 (Figure 3(a) and (b)). For a longer perspective we can use 2.5-year nssCa data, the resulting NAMI then spans 1800-1995 (Figure 3(c)).

Of the 19 cores used in this study, 10 are suitable for constructing the NAMI proxy (they all exhibit positive associations in addition to the main reasons outlined above), thus highlighting the importance of using a suite of ice cores. The remaining cores $(03-1,01-3,01-5$, 00-5, 99-1, RIDS-A, -B, -C, and SP-95) were not used for the NAMI proxy for a number of reasons, the most important being their lack of correlation to the NCEP zonal wind field. The signals of interest in these cores are likely confounded for a number of reasons. Sites 03-1 and SP-95 are located high on the East Antarctic Plateau, far from the influence of lower tropospheric storms. Sites $01-3$ and $01-5$ are located in the eastern sector of West Antarctica, near the Ellsworth Mountains and probably receive a confounding dust input from there. Site $00-5$ is protected from incoming storms by its location behind the Executive Committee Mountains, which tend to divert
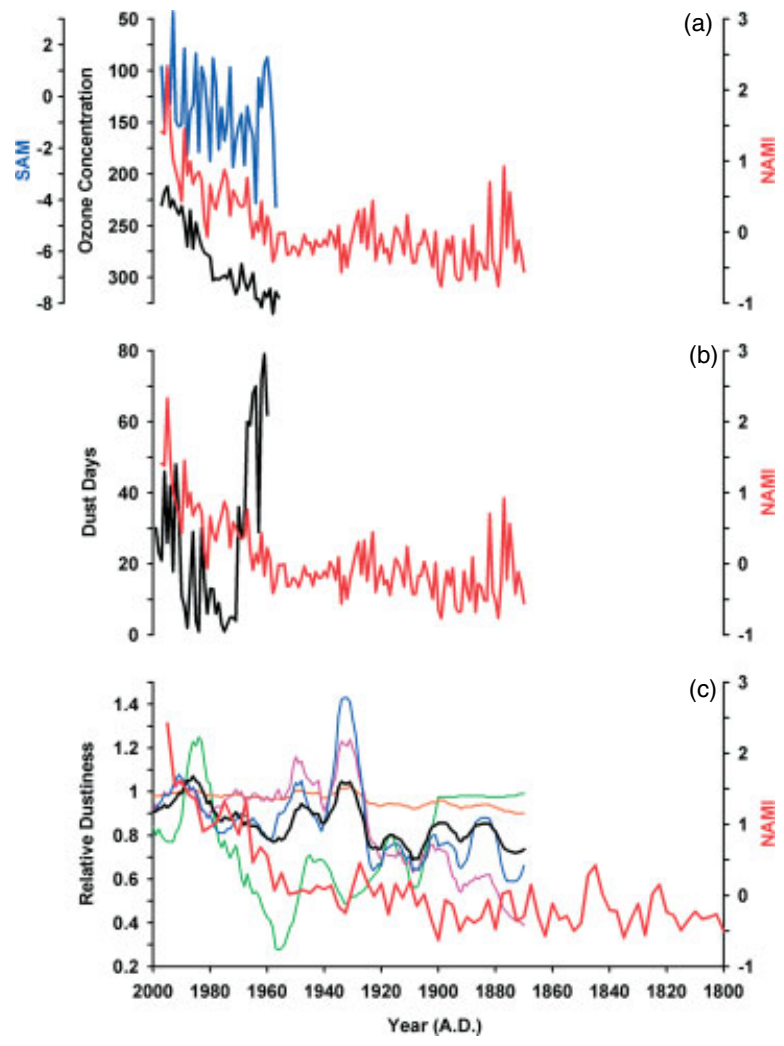

Figure 3. (a) and (b) Annual NAMI proxy 1870-1997 (red). (c) 2.5-year NAMI proxy 1800-1995 (red). Also shown, (a) total column ozone concentrations (inverted) above Halley British Antarctic Station 1956-1997 (black; (Shanklin, 2009)). SAM 1957-1997 (blue; (Marshall, 2003)) (b) Eastern Australian dust 1960-1999 (black; (BoM, 2005)). (c) SH relative dustiness data 1870-2000 (black $=\mathrm{SH}$ dust stack, blue $=$ Eastern Australia, purple $=$ South America, orange $=$ South Africa, green = North Africa; (Mahowald et al., in press)).

storms away from the site. Sites RIDS-A, -B, -C, and 99-1 are situated leeward of the main West Antarctic ice divide, in a storm shadow zone, and as a result receive less consistent precipitation input than core sites located windward of the ice divide. The CWA-A, SDM-94, and Up-C cores are also located leeward of the main West Antarctic ice divide; however, the elevation and location of these three ice-core sites are such that they still receive input from storms travelling inland across the Ross Ice Shelf.

The NAMI proxy for West Antarctica (Figure 3) reveals intensification starting between 1960 and 1970 with an abrupt increase in the rate of intensification, well above the range of natural variability, around 1980. The NAMI proxy exhibits an increasing trend similar to both the SAM (Marshall, 2003) from 1957 to 1997, and the total column ozone record (inverted) from above Halley station, Antarctica (Shanklin, 2009) from 1956 to 1997 (Figure 3(a)). Thus, the timing of the NAMI proxy increase coincides with recent intensification of the SH westerlies attributed to changes in the thermal gradient produced by modern ozone depletion and also GHG rise (Randel and Wu, 1999; Thompson and Solomon, 2002; ACCE, 2009). 
The increases observed in our NAMI proxy are likely a product of changes in transport and/or emission strength (dustiness at source). To demonstrate which of these processes might dominate, we compared the NAMI proxy to an instrumental record of dust from Eastern Australia (BoM, 2005) and to several SH dust time series extracted from a global reconstruction of dustiness (Mahowald et al., in press).

Two major dust pathways have been identified from the eastern and south-eastern seaboards of the Australian continent (McTainsh et al., 1998; Ekstrom et al., 2004; Marx et al., 2005). One pathway is associated with a strengthened mid-latitude westerly airstream coupled with a synoptic deep-low-pressure system over south-eastern Australia and the Tasman Sea that is typically related to a negative SAM climate pattern. This synoptic type transports dust east and south-east across the Tasman Sea and deposits Australian provenance dust in New Zealand, particularly the South Island (Marx et al., 2009). The second pathway is associated with a weakened westerly circulation over the mid-latitudes in the Australian region, with a poleward sub-tropical ridge and embedded high pressure system over south-eastern Australia, the southern Tasman Sea, and New Zealand. This produces northerly winds over south-eastern Australia and transports Australian dust southwards towards the drifting low-pressure systems in the westerlies and is typically associated with positive SAM circulation patterns (De Deckker et al., 2010). These dust transporting synoptic types are particularly dominant in the Austral summer and spring, and the FT analyses shown in Figure 2 support these observations.

An Australian Bureau of Meteorology dust record (BoM, 2005) from 1960 to 1999 comprises days per month of dust activity. We summed the monthly dust activity data to generate annual time series for 19601999, data are shown in Figure 3(b) for the combined eastern Australia Mulga and Darling River basins. The eastern Australian dust trend generally declines since the 1960s, dips in the 1970s, and then rises into the 1990s. As evidenced also by the FT, factors affecting dust entrainment and transport (Ekstrom et al., 2004) from continental Australia are extremely variable, and correlations between the eastern Australian dust records and the NAMI proxy are not statistically significant. Despite lacking a statistically significant correlation, it should be noted that the trend of eastern Australian dust activity flips in the middle 1970s and from that point onwards both it and the NAMI proxy exhibit a positive trend. This is consistent with the observed increasing pressure anomaly associated with increased blocking high activity over the Tasman Sea and New Zealand region during spring (Streten, 1977). This is a major anomaly in the first empirical orthogonal function (EOF) of the $\mathrm{SH}$ pressure field over the past few decades, described by the SAM (Hall and Visbeck, 2002) and has also been identified in GCMs as a signature of anthropogenic climate change (Cai et al., 2003).
Mahowald et al. (in press) use a combination of model provenance and geochemical provenance studies to produce a global dataset of dustiness from 1870 to 2000. Four dust time series from the Mahowald et al. dataset representing North Africa, South Africa, South America, and eastern Australia appear in Figure 3(c). North Africa is included because the inter-hemispheric transport of dust from the Northern Hemisphere to the $\mathrm{SH}$ is significant, particularly for dust reaching Antarctica (Li et al., 2008). The latter three overlap the locations covered by the FT used in this study. A fifth time series is constructed by averaging the four aforementioned dust time series. This averaged series is used to represent relative dustiness in the $\mathrm{SH}$ atmosphere (Figure 3(c)). None of the dust series exhibit comparable variability to the NAMI proxy. This lends further support to the idea that the NAMI proxy is dominated by atmospheric circulation and storm intensity rather than change in dust source conditions or emissions.

A separate study of dust concentrations from a northern Antarctic Peninsula ice core (McConnell et al., 2007) suggests dust concentrations starting to rise around 1900, coincident with Patagonian warming. However, this increase occurs $\sim 60$ years before any such rise in the NAMI proxy. Li et al. (2008) conduct a model-based investigation of dust transport in the SH using the GFDL atmospheric model. They suggest that Patagonian dust is transported primarily through the boundary layer of the atmosphere and dominates the half of the hemisphere comprising the Atlantic and Indian oceans, thus making it highly unlikely to be a significant source for most of West Antarctica. Further, Li et al. show that Australian dust is transported primarily through the mid-troposphere, dominates the Pacific sector, and is the most significant dust source for West Antarctica and for the whole $\mathrm{SH}$ in general.

De Deckker et al. (2010) reinforce the conclusions of $\mathrm{Li}$ et al. (2008) by using atmospheric observations and model runs to show that Australia is the primary source of dust to West Antarctica, particularly during interglacial periods. Whilst we cannot break the NAMI proxy record down into seasonal components, due to lack of significant seasonality in the nssCa signal, it is possible that increasing frequencies of mid-latitude blocking highs in association with an expanded Hadley circulation (a signature of anthropogenic climate change in the Australian/South-West Pacific region, as shown in AR4 (IPCC, 2007) models), particularly in austral summer, are increasing dust transport to the high latitudes.

The NAMI proxy curve exhibits a significant $(\mathrm{r}=$ $>0.45, p=<0.01$ ) correlation with the NCEP/NCAR reanalysis 1948-1997, January to December, $850 \mathrm{mb}$ zonal wind field in the area of the ACV (Figure 4(a)). We use $850 \mathrm{mb}$ because it is a good approximation to the lower troposphere over the study region. Using the more recent period of the NCEP record (1980-1997), which is considered to be more reliable (Hines et al., 2000), results in a similar correlation field, although reduced in strength and with lower significance $(r=>0.4, p=<0.1)$ due to 

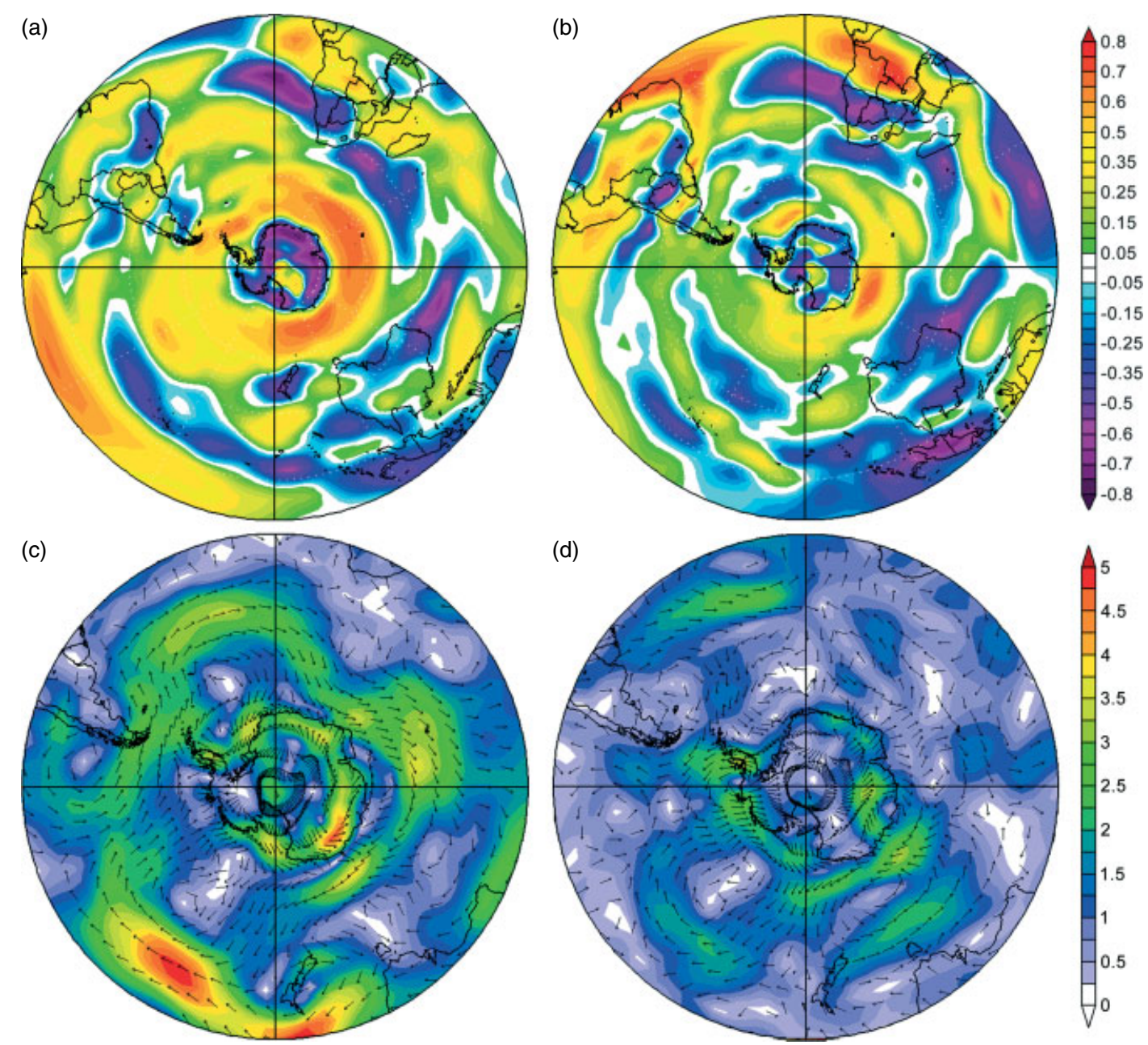

Figure 4. Correlation field between the annually averaged composite nssCa time series and the NCEP/NCAR reanalysis for (a) 1948-1997, and (b) 1980-1997, January to December, $850 \mathrm{mb}$ zonal wind field ( $r$-values above 0.37 and 0.59 represent significance above $99 \%$, respectively). September, $850 \mathrm{mb}$ vector wind composite mean for (c) 1990s minus 1950s, and (d) 1990s minus 1980s. (Images provided by the NOAA-ESRL Physical Sciences Division, Boulder Colorado from their Web site at http://www.cdc.noaa.gov/). Upper scale represents $r$-values for (a) and (b). Lower scale represents winds speeds for (c) and (d).

the reduced number of samples (Figure 4(b)). The spatial distribution of the $r$-values in Figure 4(a) and (b) (annular bands arranged more-or-less latitudinally) imply that westerly wind speeds around Antarctica increase concurrently with West Antarctic nssCa concentrations. Investigation of atmospheric circulation around Antarctica using the $850 \mathrm{mb}$ vector wind from the NCEP/NCAR reanalysis [subtracting the 1980s from the 1990s (Figure 4(d)) and subtracting the 1950s from the 1990s (with the caveat that the record is more reliable since 1980 onwards) (Figure 4(c))] reveals, in recent decades, an increase in the strength of onshore winds along the West Antarctic coastline. These onshore winds impact the NAMI icecore proxy sites inland by increasing their exposure to, and hence concentration of, SH dust.

West Antarctica is a region impacted by cyclonic storm incursions. The sub-annual nssCa time series that ultimately comprise our NAMI proxy do not display a particular seasonality, hence our proxy represents relative intensity related to storms entering West Antarctica throughout the year.
To further determine the relative significance of competing influences on our NAMI proxy, we conduct EOF analyses using three different time series representing various aspects of SH climate. EOF analysis compares multiple variates simultaneously and provides an organized description of the dominant patterns of variability among them. We use the SAM (Marshall, 2003) to represent the strength of westerly wind around Antarctica, the second principal component of $850 \mathrm{hPa}$ geopotential height anomalies south of $20^{\circ} \mathrm{S}$ (Thompson and Wallace, 2000) to represent the dominant behaviour of the ASL, and the four Mahowald et al. (in press) dust records, averaged, to represent relative dustiness of the $\mathrm{SH}$ atmosphere. We run two separate EOFs, one using nondetrended and another using detrended data. We run the latter EOF, with detrended data, to specifically exclude time series associations caused by long-term trends. In each case we use annually derived data.

Using the non-detrended data, $\sim 75 \%$ of the NAMI proxy is represented by EOF 1 along with $\sim 26 \%$ of the SAM and $\sim 67 \%$ of the SH dust, all positively associated 
Table III. EOF tables for non-detrended and detrended data.

\begin{tabular}{lr}
\hline Non-detrended & EOF 1 \\
\hline \% Variance & 42.4 \\
NAMI & 74.6 \\
SAM & 25.6 \\
ASL & -2.0 \\
SH dust stack & 67.4 \\
& \\
Detrended & EOF 2 \\
\hline \% Variance & 29.4 \\
NAMI & 77.1 \\
SAM & 0.0 \\
ASL & -35.8 \\
SH dust stack & -4.9 \\
\hline
\end{tabular}

$\%$ Variance, percent variance explained of total data.

(Table III). Plotting the EOF 1 loading pattern next to the SAM, SH dust, and NAMI reveals a similar increasing trend exhibited by all. However, the trend of $\mathrm{SH}$ dustiness reverses during the mid-1980s and decreases into the late 1990s. This declining trend in SH dustiness since the mid-1980s is not mirrored by the NAMI or the SAM (Figure 5(a)).

Using the detrended data, $\sim 77 \%$ of the NAMI proxy is represented by EOF 2 along with $\sim 36 \%$ of the ASL (Table III). The ASL is negatively correlated with the NAMI indicating that as the ASL deepens, more dust is transported into West Antarctica (Table III). Plotting the EOF 2 loading pattern with the NAMI and ASL highlights this association (Figure 5(b)). These results support our suggestion that the majority of the dust reaching central West Antarctica is transported through the lower atmosphere by storms.

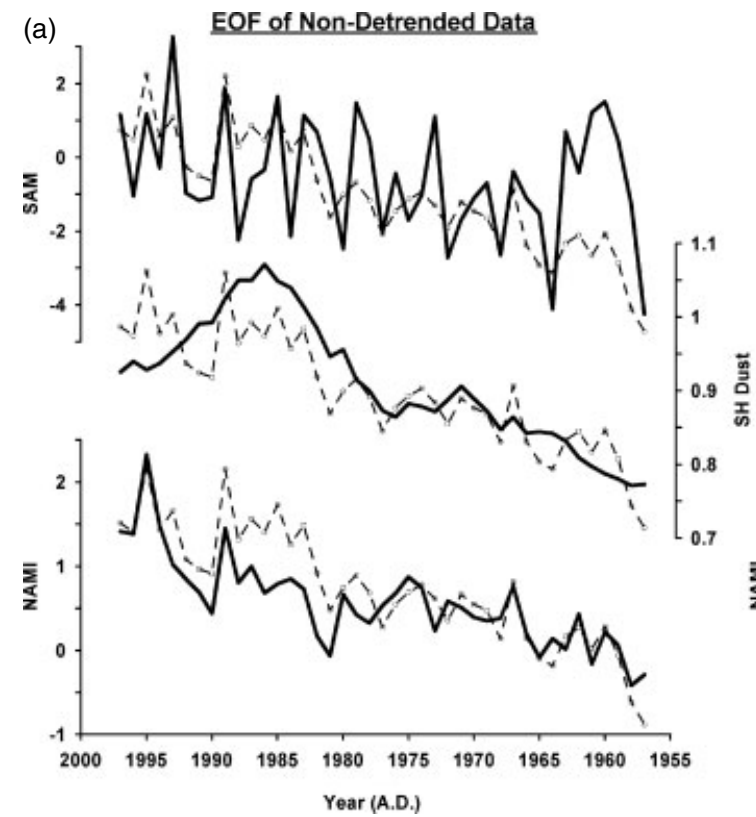

\section{Conclusions}

Understanding the anthropogenic impact on Antarctic climate is critical for the accurate assessment of future change. Our ice-core nssCa records provide a unique perspective on $\mathrm{SH}$ atmospheric circulation over the past 200 years. It is probable that large variations in dustiness at the primary $\mathrm{SH}$ dust source areas, particularly Australia, impact West Antarctic nssCa concentrations. However, as demonstrated above, our findings suggest that $\mathrm{SH}$ westerlies and ASL storm intensity are the dominant factors influencing annual variability in nssCa concentrations at the central and western West Antarctic ice-core sites used in this study.

The decadal trend in the SAM, since the 1950s, is reflected by the trend of the non-detrended NAMI proxy. However, the detrended NAMI proxy is more closely associated with the annual variability of ASL. Turner et al. (2009) find that the trend towards stronger cyclonic circulation over the Amundsen Sea since the late 1970 s is primarily a result of strengthened autumn wind speeds around the continent caused by stratospheric ozone depletion. Despite the ozone hole being an austral spring phenomena, its impact on lower atmospheric flow is greatest during summer and autumn (Turner et al., 2009). Supported by our EOF results, this finding highlights the fact that nssCa concentrations in central West Antarctica are primarily influenced by changes in $\mathrm{SH}$ atmospheric circulation intensity as opposed to dust source emissions.

The ice-core nssCa-based NAMI proxy suggests that the recent intensification of the $\mathrm{SH}$ westerlies and associated increase in ASL storm intensity are unprecedented for at least the past 200 years, underscoring the impact of CFC-induced ozone destruction. The implications of ozone recovery on an already warming Antarctic continent are worrisome (Perlwitz et al., 2008). The modern

(b)
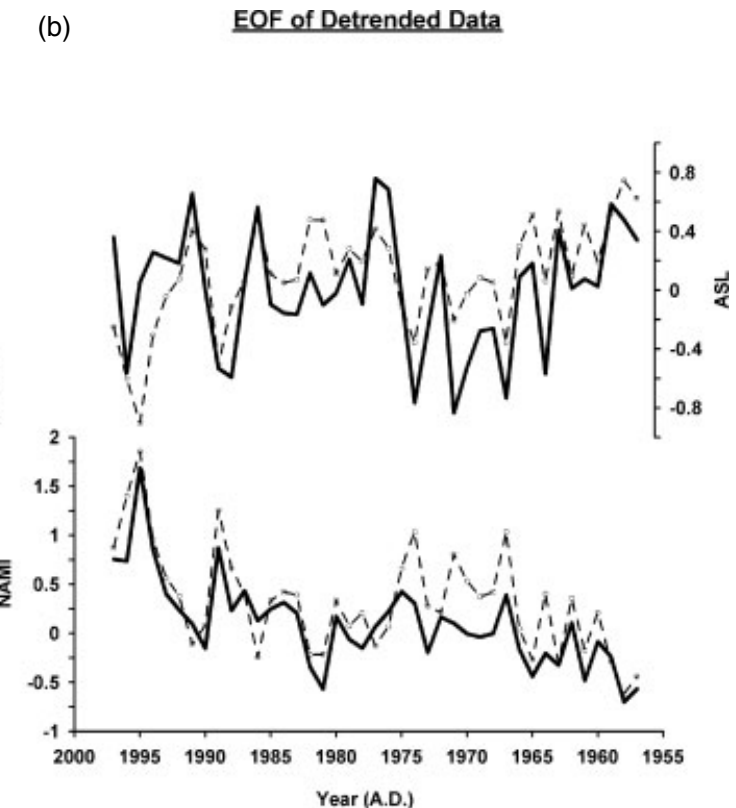

Figure 5. EOFs of (a) non-detrended, and (b) detrended data. In both cases the EOF is the dashed black line with circles. (b) Top EOF is inverted. 
ozone hole over Antarctica acts to increase the thermal gradient between the Pole and the mid-latitudes by cooling the polar stratosphere. The ozone depletioninduced thermal gradient increase strengthens the westerlies and shields interior East Antarctica from the bulk of SH warming, and in addition cools East Antarctica by reducing heat flux into the surface via weakened katabatic winds. Anderson et al. (2009) link intensification of the $\mathrm{SH}$ westerlies at the end of the last glacial period to an increase in atmospheric $\mathrm{CO}_{2}$ concentrations through upwelling of $\mathrm{CO}_{2}$-rich deep ocean water. This mechanism, although currently weak, is likely to further enhance rise of atmospheric $\mathrm{CO}_{2}$. Mayewski et al. (2004) propose changes in temperature and atmospheric circulation over coastal West Antarctica coincident with the rise in $\mathrm{CO}_{2}$ that may mark the earliest impact of human activity on the climate of Antarctica

Ozone recovery will likely weaken the SH westerlies, particularly during the Austral spring-summer. Consequently, Antarctica could lose one of its best defences against SH GHG warming. This potential consequence is similar to the impact of humans in the Northern Hemisphere where sulfate aerosols temporarily reduced the warming effects of GHG rise from 1940s to 1970s.

\section{Acknowledgements}

This research was supported by the US National Science Foundation Office of Polar Programs grants (0096305, 0096299, 0439589, 063740, 063650 and 0837883) and the W.M. Keck Foundation to P.M. We thank the US Antarctic Program, the 109th N.Y. Air National Guard, Ice Core Drilling Services, Raytheon Polar Services Company and our US ITASE field colleagues for their support.

\section{References}

Abram NJ, Mulvaney R, Wolff EW, Mudelsee M. 2007. Ice core records as sea ice proxies: an evaluation from the Weddell Sea region of Antarctica. Journal of Geophysical Research-Atmospheres 112: D15101, DOI:10.1029/2006jd008139.

ACCE. 2009. Antarctic Climate Change and the Environment, Turner J, Bindschadler R, Convey P, Prisco Gd, Fahrbach E, Gutt J, Hodgson D, Mayewski P, Summerhayes C (eds). Scientific Committee on Antarctic Research: Cambridge, UK, 555. pp.

Anderson RF, Ali S, Bradtmiller LI, Nielsen SHH, Fleisher MQ, Anderson BE, Burckle LH. 2009. Wind-Driven upwelling in the Southern Ocean and the deglacial rise in atmospheric $\mathrm{CO}_{2}$. Science 323: 1443-1448, DOI:10.1126/science.1167441.

Bertler N, Mayewski PA, Aristarain A, Barrett P, Becagli S, Bernardo R, Bo S, Xiao C, Curran M, Qin D, Dixon D, Ferron F, Fischer H, Frey M, Frezzotti M, Fundel F, Genthon C, Gragnani R, Hamilton G, Handley M, Hong S, Isaksson E, Kang J, Ren J, Kamiyama K, Kanamori S, Karkas E, Karlof L, Kaspari S, Kreutz K, Kurbatov A, Meyerson E, Ming Y, Zhang M, Motoyama H, Mulvaney R, Oerter H, Osterberg E, Proposito M, Pyne A, Ruth U, Simoes J, Smith B, Sneed S, Teinila K, Traufetter F, Udisti R, Virkkula A, Watanabe O, Williamson B, Winther JG, Li Y, Wolff E, Li Z, Zielinski A. 2005. Snow chemistry across Antarctica. Annals of Glaciology 41: 167-179.

BoM. 2005. Climate Data: Australia, Version 2.2. Bureau of Meteorology. Australian Government.

Cai W, Whetton PH, Karoly DJ. 2003. The response of the Antarctic oscillation to increasing and stabilized atmospheric $\mathrm{CO}_{2}$. Journal of Climate 16: $1525-1538$.
Crook JA, Gillett NP, Keeley SPE. 2008. Sensitivity of Southern Hemisphere climate to zonal asymmetry in ozone. Geophysical Research Letters 35: L07806, DOI:10.1029/2007gl032698.

Curran MAJ, van Ommen TD, Morgan VI, Phillips KL, Palmer AS. 2003. Ice core evidence for Antarctic sea ice decline since the 1950s. Science 302: 1203-1206.

De Deckker P, Norman M, Goodwin I, Wain A, Gingele F. 2010. Lead isotopic evidence for an Australian source of aeolian dust to Antarctica at times over the last 170,000 years. Palaeogeography, Palaeoclimatology, Palaeoecology 285: 205-223, DOI:10.1016/j.palaeo.2009.11.013.

Dixon D, Mayewski PA, Kaspari S, Sneed S, Handley M. 2004. A 200 year sub-annual record of sulfate in West Antarctica, from 16 ice cores. Annals of Glaciology 39: 545-556.

Draxler RR, Rolph GD. 2003. HYSPLIT (HYbrid Single-Particle Lagrangian Integrated Trajectory) Model. Silver Spring, MD. NOAA Air Resources Laboratory. Available at http://www.arl.noaa.gov/ HYSPLIT_info.php.

Ekstrom M, McTainsh GH, Chappell A. 2004. Australian dust storms: temporal trends and relationships with synoptic pressure distributions (1960-99). International Journal of Climatology 24: 1581-1599, DOI:10.1002/joc.1072.

Gayley RI, Ram M. 1985. Atmospheric dust in polar ice and the background aerosol. Journal of Geophysical Research-Atmospheres 90: $2921-2925$.

Hall A, Visbeck M. 2002. Synchronous variability in the southern hemisphere atmosphere, sea ice, and ocean resulting from the annular mode. Journal of Climate 15: 3043-3057.

Hines KM, Bromwich DH, Marshall GJ. 2000. Artificial surface pressure trends in the NCEP-NCAR reanalysis over the southern ocean and Antarctica. Journal of Climate 13: 3940-3952.

Holland HD. 1978. The Chemistry of the Atmosphere and Oceans, John Wiley \& Sons Inc: New York, 369. pp.

IPCC. 2007. Climate change 2007: the physical science basis. In Contribution of Working Group 1 to the Fourth Assessment Report of the Intergovernmental Panel on Climate Change., Solomon S, Qin D, Manning M, Marquis M, Averyt K, Tignor MMB, Miller HL, Chen Z (eds). Cambridge University Press: Cambridge, UK and New York, NY, USA, 996. pp.

Kaspari S, Mayewski PA, Dixon DA, Spikes VB, Sneed SB, Handley MJ, Hamilton GS. 2004. Climate variability in West Antarctica derived from annual accumulation-rate records from ITASE firn/ice cores. Annals of Glaciology 39: 585-594.

Kreutz KJ, Mayewski PA, Pittalwala II, Meeker LD, Twickler MS, Whitlow SI. 2000. Sea level pressure variability in the Amundsen Sea region inferred from a West Antarctic glaciochemical record. Journal of Geophysical Research-Atmospheres 105: 4047-4059.

Legrand M, Mayewski P. 1997. Glaciochemistry of polar ice cores: a review. Reviews of Geophysics 35: 219-243.

Li F, Ginoux P, Ramaswamy V. 2008. Distribution, transport, and deposition of mineral dust in the Southern Ocean and Antarctica: Contribution of major sources. Journal of Geophysical Research 113: D10207, DOI:10.1029/2007jd009190.

Lubin D, Wittenmyer RA, Bromwich DH, Marshall GJ. 2008. Antarctic Peninsula mesoscale cyclone variability and climatic impacts influenced by the SAM. Geophysical Research Letters 35: L02808, DOI: $10.1029 / 2007 \mathrm{gl} 032170$

Mahowald NM, Kloster S, Engelstaedter S, Moore JK, Mukhopadhyay S, McConell JR, Albani S, Doney SC, Bhattacharya A, Curran MAJ, Flanner MG, Hoffmann FM, Lawrence DM, Lindsay K, Mayewski PA, Neff J, Rothenberg D, Thomas E, Thornton PE, Zender CS. 2010. Observed 20th century desert dust variability: impact on climate and biogeochemistry. Atmos. Chem. Phys. 10: 10875-10893, DOI:10.5194/acp-10-10875-2010.

Marshall GJ. 2003. Trends in the southern annular mode from observations and reanalyses. Journal of Climate 16: 4134-4143.

Marx SK, Kamber BS, McGowan HA. 2005. Provenance of longtravelled dust determined with ultra-trace-element composition: a pilot study with samples from New Zealand glaciers. Earth Surface Processes and Landforms 30: 699-716, DOI:10.1002/esp.1169.

Marx SK, McGowan HA, Kamber BS. 2009. Long-range dust transport from eastern Australia: a proxy for Holocene aridity and ENSO-type climate variability. Earth and Planetary Science Letters 282: 167-177, DOI:10.1016/j.epsl.2009.03.013.

Mayewski PA, Maasch KA, White JWC, Steig EJ, Meyerson E, Goodwin I, Morgan VI, Van Ommen T, Curran MAJ, Souney J, Kreutz K. 2004. A 700 year record of Southern Hemisphere extratropical climate variability. Annals of Glaciology 39: $127-132$. 
Mayewski PA, Frezzotti M, Bertler N, Van Ommen T, Hamilton G, Jacka TH, Welch B, Frey M, Qin D, Ren JW, Simoes J, Fily M, Oerter H, Nishio F, Isaksson E, Mulvaney R, Holmund P, Lipenkov V, Goodwin I. ITASE. 2005. The International TransAntarctic Scientific Expedition (ITASE): an overview. Annals of Glaciology 41: 180-185.

Mayewski PA, Meredith MP, Summerhayes CP, Turner J, Worby A, Barrett PJ, Casassa G, Bertler NAN, Bracegirdle T, Naveira Garabato AC, Bromwich D, Campbell H, Hamilton GS, Lyons WB, Maasch KA, Aoki S, Xiao C, van Ommen T. 2009. State of the Antarctic and Southern Ocean climate system. Reviews of Geophysics 47: RG1003, DOI:10.1029/2007rg000231.

McConnell JR, Aristarain AJ, Banta JR, Edwards PR, Simoes JC. 2007. 20th-Century doubling in dust archived in an Antarctic Peninsula ice core parallels climate change and desertification in South America. Proceedings of the National Academy of Sciences of the United States of America 104: 5743-5748, DOI:10.1073/pnas.0607657104.

McTainsh GH, Lynch AW, Tews EK. 1998. Climatic controls upon dust storm occurrence in eastern Australia. Journal of Arid Environments 39: 457-466, DOI:10.1006/jare.1997.0373.

Meyerson EA, Mayewski PA, Kreutz KJ, Meeker LD, Whitlow SI, Twickler MS. 2002. The polar expression of ENSO and sea-ice variability as recorded in a South Pole ice core. Annals of Glaciology 35: $430-436$.

Monaghan AJ, Bromwich DH, Chapman W, Comiso JC. 2008. Recent variability and trends of Antarctic near-surface temperature. Journal of Geophysical Research-Atmospheres 113: D04105, DOI:10.1029/2007jd009094.

O'Brien SR, Mayewski PA, Meeker LD, Meese DA, Twickler MS, Whitlow SI. 1995. Complexity of Holocene climate as reconstructed from a Greenland ice core. Science 270: 1962-1964.

Osterberg EC, Handley MJ, Sneed SB, Mayewski PA, Kreutz KJ. 2006. Continuous ice core melter system with discrete sampling for major ion, trace element, and stable isotope analyses. Environmental Science \& Technology 40: 3355-3361, DOI:10.1021/es052536w.

Perlwitz J, Pawson S, Fogt RL, Nielsen JE, Neff WD. 2008. Impact of stratospheric ozone hole recovery on Antarctic climate. Geophysical Research Letters 35: L08714, DOI:10.1029/2008g1033317.

Prospero JM, Ginoux P, Torres O, Nicholson SE, Gill TE. 2002. Environmental characterization of global sources of atmospheric soil dust identified with the Nimbus 7 Total Ozone Mapping Spectrometer (TOMS) absorbing aerosol product. Reviews of Geophysics 40: 1002, DOI: $10.1029 / 2000 \operatorname{rg} 000095$.

Randel WJ, Wu F. 1999. Cooling of the arctic and antarctic polar stratospheres due to ozone depletion. Journal of Climate 12: $1467-1479$.

Rignot E, Casassa G, Gogineni P, Krabill W, Rivera A, Thomas R. 2004. Accelerated ice discharge from the Antarctic Peninsula following the collapse of Larsen B ice shelf. Geophysical Research Letters 31: L18401, DOI:10.1029/2004g1020697.

Scambos TA, Bohlander JA, Shuman CA, Skvarca P. 2004. Glacier acceleration and thinning after ice shelf collapse in the Larsen B embayment, Antarctica. Geophysical Research Letters 31: L18402, DOI:10.1029/2004gl020670.

Schneider DP, Steig EJ, Comiso JC. 2004. Recent climate variability in Antarctica from satellite-derived temperature data. Journal of Climate 17: 1569-1583.
Schneider DP, Steig EJ, van Ommen TD, Dixon DA, Mayewski PA, Jones JM, Bitz CM. 2006. Antarctic temperatures over the past two centuries from ice cores. Geophysical Research Letters 33: L16707, DOI:10.1029/2006gl027057.

Shanklin JD. 2009. Total column ozone record from above Halley station, Antarctica. British Antarctic Survey, Madingley Road, Cambridge, England. CB3 0ET. Available at http://www. antarctica.ac.uk/met/jds/ozone/data/ZOZ5699.DAT (accessed on January 2009).

Shaw GE. 1979. Considerations on the origin and properties of the Antarctic aerosol. Reviews of Geophysics 17: 1983-1998.

Steig EJ, Mayewski PA, Dixon DA, Kaspari SD, Frey MM, Schneider DP, Arcone SA, Hamilton GS, Spikes VB, Albert M, Meese D, Gow AJ, Shuman CA, White JWC, Sneed S, Flaherty J, Wumkes M. 2005. High-resolution ice cores from USITASE (West Antarctica): development and validation of chronologies and determination of precision and accuracy. Annals of Glaciology 41: 77-84. Steig EJ, Schneider DP, Rutherford SD, Mann ME, Comiso JC, Shindell DT. 2009. Warming of the Antarctic ice-sheet surface since the 1957 International Geophysical Year. Nature 457: 459-462, DOI:10.1038/nature07669.

Streten NA. 1977. Aspects of year-to-year variation of seasonal and monthly mean station temperature over southern-hemisphere. Monthly Weather Review 105: 195-206.

Thompson DWJ, Wallace JM. 2000. Annular modes in the extratropical circulation. Part I: Month-to-month variability. Journal of Climate 13: 1000-1016.

Thompson DWJ, Solomon S. 2002. Interpretation of recent Southern Hemisphere climate change. Science 296: 895-899.

Thompson DWJ, Wallace JM, Hegerl GC. 2000. Annular modes in the extratropical circulation. Part II: Trends. Journal of Climate 13: 1018-1036.

Tuncel G, Aras NK, Zoller WH. 1989. Temporal variations and sources of elements in the South-Pole atmosphere. 1. Nonenriched and moderately enriched elements. Journal of Geophysical ResearchAtmospheres 94: 13025-13038.

Turner J, Lachlan-Cope TA, Colwell S, Marshall GJ, Connolley WM. 2006. Significant warming of the Antarctic winter troposphere. Science 311: 1914-1917, DOI:10.1126/science.1121652.

Turner J, Comiso JC, Marshall GJ, Lachlan-Cope TA, Bracegirdle T, Maksym T, Meredith MP, Wang ZM, Orr A. 2009. Non-annular atmospheric circulation change induced by stratospheric ozone depletion and its role in the recent increase of Antarctic sea ice extent. Geophysical Research Letters 36: L08502, DOI:10.1029/2009gl037524.

van den Broeke M. 2005. Strong surface melting preceded collapse of Antarctic Peninsula ice shelf. Geophysical Research Letters 32: L12815, DOI:10.1029/2005gl023247.

van den Broeke MR, van Lipzig NPM. 2004. Changes in Antarctic temperature, wind and precipitation in response to the Antarctic Oscillation. Annals of Glaciology 39: 119-126.

Welch KA, Mayewski PA, Whitlow SI. 1993. Methanesulfonic-acid in coastal Antarctic snow related to sea-ice extent. Geophysical Research Letters 20: 443-446.

Yan YP, Mayewski PA, Kang SC, Meyerson E. 2005. An ice-core proxy for Antarctic circumpolar zonal wind intensity. Annals of Glaciology 41: 121-130. 